\title{
Study on the Impact of New Accounting Standards on Earnings Management
}

\author{
Jinping SUN \\ Department of Finance, Yangjiang Vocational and Technical College, Yangjing 529566, Guangdong, China
}

\begin{abstract}
Earning management is a very hot and disputed topic can be influenced by many factors. Compared to old standards, our new accounting standards can restrict earning management in lots of aspects. Inevitably, as immature standards, it can't avoid and eradicate all the situations in earning management. This paper will compare the difference between the old and new standards and research its impact on earnings management.
\end{abstract}

KEYWORD: New accounting standards; Difference; Earning management; Impact

\section{INTRODUCTION}

There are many scholars have studied earnings management from different sides and aspects. As a result, earnings management have so many definitions. This paper will classify it according to home and abroad.

William.R.Scott from US points out those enterprise mangers will choose the most favorable accounting policy[1]. Consequently, earnings management is a result of accounting policy. In William's mind, earning management is the behavior of maximizing their profits using the accounting policy in the allowance of GAAP[2]. Obviously, William limited the earning management into a narrow rage.

Kathehne Schipper states the aim of earnings management is to get some personal benefits[3]. His definition is not very comprehensive because he thought management equals to data adjusting in the financial reports.

Healy and Wahlen regard earnings management as adopting the financial reports in order to mislead those people who make decisions according to the report data[4], The author considers the real business is also a kind of earning management, which is much more comprehensive than the above two[5].

Mr.Lu Jianqiao's definition is quite similar to William[6]. He defines earnings management is choosing different accounting policy for the purpose of maximizing their utility and value.

Mr.Zhang Yongkui and Mr.Liu Feng hold the idea that manipulating the profit on purpose out of the accounting standards is earning management[7].
We can see that different scholars' explanations vary a lot. Combining the explanations both home and abroad, this paper will give the definitions on earnings management as follow: earnings management is the kind of processing behavior on financial data using the false trade, accounting policy and corporation strategy. Of course, the processing behavior includes the legal ones and illegal ones. Narrow sense on earning management refers to the illegal behavior, which doesn't match this paper.

\section{THE DIFFERENCE BETWEEN THE NEW AND OLD ACCOUNTING STANDARDS}

The new accounting standards made lots of changes compared to the old standards. In order to contrast with each other, we've made a chart. The details can be seen from Table 1.

\section{HOW THE NEW ACCOUNTING} STANDARDS EFFECT THE EARNINGS, INCLUDING THE POSITIVE AND NEGATIVE SIDES

\subsection{The positive sides----the restriction on earning management}

(1) The inventory criterion formulates first-in firstout method, method of weighted mean and individual pricing as the valuation method, and cancels the last-in first-out method and moving weighted average method. The valuation method's impact on profit reflects on the price fluctuation. If 
the last-in first-out method is allowed, the enterprise's profit will decline falsely when the inventory's price rises, and vice-versa. Clearly, lastin first-out method had been a effective ways to adopt profit. The revise on accounting standards will make enterprise reflect their inventory more authentically and restrict earning management.

Table 1. The difference between the new accounting standards and old accounting standards.

\begin{tabular}{|c|c|c|}
\hline Item & New standards & Old Standards \\
\hline $\begin{array}{l}\text { sending out } \\
\text { stocks' valuation }\end{array}$ & $\begin{array}{l}\text { individual pricing, first-in first-out method, method of weighted } \\
\text { mean }\end{array}$ & $\begin{array}{l}\text { individual pricing, first-in first-out method, } \\
\text { method of weighted mean ,moving average } \\
\text { method, last-in first-out method }\end{array}$ \\
\hline borrowing costs & $\begin{array}{l}\text { interest from ordinary debits for fixed assets, inventory ,invested } \\
\text { real estate and so on which cost long time for ready can be } \\
\text { capitalized }\end{array}$ & $\begin{array}{l}\text { All the borrowing costs should taken into } \\
\text { financial cost. }\end{array}$ \\
\hline $\begin{array}{l}\text { long-term equity } \\
\text { investment }\end{array}$ & $\begin{array}{l}\text { If the investment enterprise has joint control or significant influence } \\
\text { on the invested entity ,then the long-term equity investments should } \\
\text { be used equity method ; If the investment enterprise controls the } \\
\text { invested entity, then costing method is available. }\end{array}$ & $\begin{array}{l}\text { If the investment enterprise has control, } \\
\text { joint control or significant influence on the } \\
\text { invested entity ,then the long-term equity } \\
\text { investments should be used equity method }\end{array}$ \\
\hline fixed & $\begin{array}{l}\text { 1. Discard cost should be taken into consideration when computing } \\
\text { fixed assets - cost. } \\
\text { 2. When the assets buying period is beyond the normal credit } \\
\text { conditions and has financing essence, then the cost of fixed assets } \\
\text { should be based on its present value. The difference between the } \\
\text { present value and bill actually paid should be in } \\
\text { unacknowledged financial charges. } \\
\text { 3. Impairment loss for fixed assets mustn't be turned back. }\end{array}$ & $\begin{array}{l}\text { 1. Take no account of deferred payment or } \\
\text { interest. } \\
\text { 2. Impairment loss for fixed assets can be } \\
\text { turned back. }\end{array}$ \\
\hline Intangible asset & $\begin{array}{l}\text { 1. Goodwill is not in the scale of intangible asset. } \\
\text { 2. Impairment loss for intangible assets mustn't be turned back } \\
\text { 3.The expenditure on research stage will be in profit and the } \\
\text { expenditure on development stage will be confirmed as intangible } \\
\text { assets. } 4 \text {. intangible assets with limited service life should be tested } \\
\text { at the end of each year to see whether the service life is proper. }\end{array}$ & $\begin{array}{l}\text { 1. Goodwill is a kind of non-identifiable } \\
\text { intangible asset. } 2 \text {. The expenditure on } \\
\text { research stage and development stage will } \\
\text { be in profit will be confirmed as profit. }\end{array}$ \\
\hline debt restructuring & The gain or loss will be in current profit and loss. & The $\mathrm{g}$ \\
\hline income & $\begin{array}{l}\text { 1.Income should be based on the price in the contract, unless the } \\
\text { price is not fair and just. 2. When the charge is by the way of } \\
\text { deferring and financing, the income should be determined by the } \\
\text { fair value. }\end{array}$ & $\begin{array}{l}\text { Income should be determined by the price } \\
\text { in the contract in every situation, namely } \\
\text { the name value controls income. }\end{array}$ \\
\hline borrowing costs & $\begin{array}{l}\text { Specialized borrowing costs and ordinary borrowing costs are all } \\
\text { can be capitalized. }\end{array}$ & $\begin{array}{l}\text { Only specialized borrowing costs can be } \\
\text { capitalized. }\end{array}$ \\
\hline $\begin{array}{l}\text { accounting policy, } \\
\text { accounting } \\
\text { estimate change, } \\
\text { correction of } \\
\text { accounting error }\end{array}$ & $\begin{array}{l}\text { 1. The new standards just stipulate prior period errors and do not } \\
\text { distinguish significant and not significant mistakes any more } \\
\text { 2. Retrospective Restatement is used to correct previous mistakes. }\end{array}$ & $\begin{array}{l}\text { 1.The mistakes include current period } \\
\text { mistakes and prior period errors. } \\
\text { 2.Prior period errors can be classified into } \\
\text { significant and not significant mistakes. } \\
\text { What's more, each kind mistakes use } \\
\text { different ways to handle. }\end{array}$ \\
\hline
\end{tabular}

(2) The new accounting standard stipulate that the impairment on fixed assets, construction in process ,intangible assets and long-term stock investment shouldn't be turned back since verified, which reduces the possibility of adjusting profits by confirming and turning back impairment. The initial purpose of impairment reflects moderation principle. Since it can increase or decrease the profit directly, lots of enterprises regard it as a very effective regulator.

(3)In the old standards, parent company can change the investment proportion in order to change the merge extent, resulting in earning management .Based on the essence important than form, the new standards make all controlled subcompanies into the merge extent, including the small scale companies, specific business companies and the sub-companies whose owner's equity is negative. Regardless of the investment proportion, new standards enlarge the extent, so that the parent companies cannot remove those sub-companies in bad operation for the sake of whitewashing the whole group outstanding achievement. Besides, the new standards stipulate book value is applicative to merger under the same control, which is in favor of preventing enterprises from using fair value to manipulate the operating achievement and financial condition.

(4)The new standards expand the definitions of relevance. Control, co-control and significant impact are all in the scale of relevance. Whether having relevant trades with relevance or not, companies should announce all the relevant parts, including their trade amount, trade proportion and so on. New standard not only spread the scale of relevance, but also make its details more clearly and explicitly. Therefore the transparency of relevant trade 
increases and the space for earning management decreases.

\subsection{The negative sides----the indulge in earning management}

(1)The capitalized cost doesn't just include the "interest from special debts for building the fixed assets" but also "interest from ordinary debts for fixed assets, inventory ,invested real estate and so on which cost long time for ready" .In the old standards ,only the special interest for fixed assets can be capitalized. As the enterprises always mix the use of all kinds of debts, it is quite difficult for outsiders to see how much ordinary debts have been spent on assets corresponding to the requirements above. Consequently, enterprises can increase or hide profits by adopting the capitalized interest.

(2)The new standards draw the fair value into the financial tools, investment real estate, enterprise merge not under the same control, liabilities recombination and non-currency exchange. Let's take the non-currency exchange for example. According to the new standard, enterprises should take the balance between the fair value of the contributive asset and the book value of the contributive asset into the profit and loss, which provides lots spaces for earning management. If fair value can be used properly, it can prove the relative ness of accounting information. However, when fair value is abused, things will be serious because audit department and government department can't test and verify fair value effectively. As a result, fair value can help company's management earnings consciously.

(3)The new standards expand the scale of impairment of asset. Besides inventory and former eight kinds of assets, investment real estate under the fair value econometric mode, consumptive biological assets and deferred income tax assets should be tested to see whether they have sign to decrease in value at the end of each accounting term. Although some assets' provision for diminution in value mustn't be switched back since withdraws, there're still many other assets which can be turned back if the leadership wants. And there are so many accounting choice and professional judgment in recoverable amount, net present value and discount rate that resilience space can be given to earning management.

(4) The old standards stipulate all the research and development cost should be reckoned in the profit. The new standards classify the cost into two section and allow the development cost under the eligibility criteria be numbered in intangible assets and amortized in stages. The initial meaning of this change is to redeploy enthusiasm for creativity. However, creativity for intangible assets is in high difficulty and risk and is very hard to distinguish the research stage and development stage, which will avail the earning management. In addition, amortization for intangible assets will not be confined to straight line method, so companies, especially listed companies can improve profit by reducing amortization years or changing the amortization method.

\subsection{An empirical study on the Impact of new accounting standards on earnings management}

In order to give some statistical support, we will make an empirical research. Earning management will be seen as dependent variable and some of the typical accounting standards changes as the independent variable. Details are as Table 2.

Table 2. Variable and their names

\begin{tabular}{|l|l|l|l|}
\hline $\begin{array}{l}\text { Types of } \\
\text { variables }\end{array}$ & $\begin{array}{l}\text { Names of } \\
\text { variables }\end{array}$ & symbol & Explanation \\
\hline $\begin{array}{l}\text { dependent } \\
\text { variable }\end{array}$ & total profit & TP & \\
\hline \multirow{4}{*}{$\begin{array}{l}\text { independent } \\
\text { variable }\end{array}$} & $\begin{array}{l}\text { operating } \\
\text { income }\end{array}$ & OE & $\begin{array}{l}\text { operating receipt- } \\
\text { operating costs }\end{array}$ \\
\cline { 2 - 4 } & period charge & PE & $\begin{array}{l}\text { financial cost, selling } \\
\text { expenses }\end{array}$ \\
\cline { 2 - 4 } & $\begin{array}{l}\text { impairment of } \\
\text { asset }\end{array}$ & AIL & \\
\cline { 2 - 4 } & inventory & INVY & \\
\hline
\end{tabular}

This paper has selected 50 listed companies which changed their accounting policy during the year of 2009 and 2011as the object of study.

$$
\mathrm{TP}=\alpha_{0}+a_{1} \times O E+a_{2} \times P E+a_{3} \times A I L+a_{4} \times I N V Y+\varepsilon
$$

We use SPSS 17.0 to handle all the data and work out Multiple Linear Regression (MLR, which is shown in Table 3.

Table 3. Overview of the model

\begin{tabular}{|c|c|c|c|}
\hline $\mathrm{R}$ & R Square & $\begin{array}{c}\text { Adjusted } \\
\text { R Square }\end{array}$ & $\begin{array}{c}\text { Std. Error of the } \\
\text { Estimate }\end{array}$ \\
\hline $.935 \mathrm{a}$ & .875 & .859 & $5.68521 \mathrm{E} 8$ \\
\hline
\end{tabular}

From the Table 4, we can see coefficient of association is 0.935 ; linear regression coefficient is 0.875 , so the fitting degree for the model is very high.

Table 4. Analysis of variance

\begin{tabular}{|c|c|c|c|c|c|} 
Model & Sum of Squares & df & Mean Square & F & Sig. \\
\hline Regression & $9.015 \mathrm{E} 19$ & 5 & $1.803 \mathrm{E} 19$ & 55.785 & $.000 \mathrm{a}$ \\
\hline Residual & $1.293 \mathrm{E} 19$ & 40 & $3.232 \mathrm{E} 17$ & & \\
\hline Total & $1.031 \mathrm{E} 20$ & 45 & & & \\
\hline
\end{tabular}


The significance testing of our model shows that regression sum of squares is $9.015^{*} 1019$, and the total sum of squares is $1.293 * 1019$, which show the model has reached the standards of outstanding.,

From the empirical study we can easily see that impairment of assets, fair value have great impact on the profit of listed companies. Namely, they have played an important part in earning management.

\section{CONCLUSION AND SUGGESTIONS}

Accounting standards have been carried the task of restricting earning management since it is born. On account of its technicality, accounting standards not only can confine leadership's random for accounting selection and rise the quality of accounting information, but also can be the significant gist for audit practice and security supervise. However, incompleteness and imperfection of our accounting standards result in the serious phenomenon of earning management. If nothing is done to prevent, earning management will damage accounting information's quality and go against with our economy. This paper will give such suggestions.

\subsection{Building a long-term and consistent goal for accounting standards.}

Compared to domestic standards, oversea standards like US have made the goal clearly from the very beginning[8]. Straightforward target can help investors know the companies with good performance from the bad ones.

\subsection{Establishing explicit and specific accounting standards patterning.}

The patterning can be classified as principle-based and regulation-based. Regulation-based patterning always give detailed principles for trades, items and objections, and try to take all the situations into considerations, which makes the principles into the specific regulations. Regulation-based patterning gives the roughly principles and leave enough space for enterprises to adjust. Each patterning has their own virtues and faults. How to make the explicit and specific accounting standards patterning is urgent question. Only by doing that, can we make progress in consummating our standards?

\subsection{Accounting firms and CPS should be independent.}

Accounting firms and CPA have been playing more and more important roles in our accounting market and influence the quality directly. In order to restrict earning management, accounting firms should be more independent so as to be responsible for the public and should keep objective and fair. Nowadays, lots of accounting firms recruit number of trainees to take part in the audit practices. Obviously, it is difficult for trainees to find out earning management. Rising up the threshold for auditors can also be helpful to confine earning management

\section{REFERENCES}

[1] William. R. Scott. Financial Accounting Theory, Pearson, 5(1), pp. 225-227, 2009.

[2] Segovia, Joann R, Earnings Management: do the type of GAAP, persuasive client explanation, and SEC not inflication influence the auditors' decisions?, Working Paper Texas Tech University, 4, 165-179, 2003.

[3] April Klein Audit committee, board of director characteristics, and earnings management, Journal of Accounting and Economics, 33(3), pp. 375-400, 2002.

[4] Healy, P.M, The effect of Bonus Schemes on Accounting Decisions, Journal of Business, 7(1-3), pp. 85-107, 1999.

[5] Hwa-Sung Kim, Executive bonus compensation when abnormal earnings and the state of the economy are correlated Original Research Article, Economic Modelling, 32, pp. 58-65, 2013..

[6] Lu JianQiao, An Empirical Study on Earnings management of Loss Listed Companies in China, China financial economic publishing house, pp.95-99, 2002.

[7] Zhang Yongkui, Correlation empirical between research Earnings management and audit opinions, Economic planning and management, pp. 3-9, 2002.

[8] Ball, R., and L. Shivakumar, Earnings Quality in U.K. Private Firms, Journal of Accounting and Economics, 39(2), pp. 